\title{
Study on Cultural Resources Dissemination of Canal Head of the Middle Route of the South-to-North Water Transfer Project
}

\author{
Qianqian $\mathrm{Wu}$ \\ School of Literature and Law \\ Nanyang Institute of Technology \\ Nanyang, China 473004
}

\begin{abstract}
Cultural resources are an important part of building a city image. Effective and favorable communication is a powerful means to empower a city brand. The canal head of the South-to-North Water Transfer Project middle line has a profound historical and cultural heritage. Combining with the advantages of natural resources, it strives to create cultural symbols such as "the spirit of the canal head", "Chudu Danyang" and "Hometown of Fan $\mathrm{Li}$ " so as to promote the culture of the canal head to the whole country and even the whole world. Finally, the regional culture will be greatly spread and a good city image will be established.
\end{abstract}

Keywords-South-to-North Water Transfer; canal head; culture; communication

\section{INTRODUCTION}

Xichuan has an extensive and profound regional culture. There are lots of stories forming a magnificent historical and cultural picture scroll of the middle route of the South to North Water Transfer Project, such as Nezha Conquers the Dragon King in remote date, Danzhu combating the flood in the era of Yao, Shun and $\mathrm{Yu}$, the capital and nation founding of Xiong $\mathrm{Yi}$ in the Spring and Autumn period, the war between Qin and Chu at Danyang in the Warring States period, the prosperity of the Danjiang channel in the Qin, Han and Tang Dynasties, the later Song and Jin Dynasty wars, the Jing-Xiang refugees and the establishment of Xichuan county in the Ming Dynasty, the development of Danjiang shipping to its heyday in the Qing Dynasty, which led to the promotion of Xichuan status as a Zhili hall, the breakout of Central Plains military region to force the way across the Danjiang River and break through Jingzi Pass, the emancipation of Xichuan in May 1948, and the South to North Water Transfer today. Xichuan, the canal head, is the place where the capital of Chu, named Danyang located in and the birthplace of the Chu culture in the spring and Autumn period. Moreover, the ancient architectural groups of the Jingzi Pass and Xiangyan Temple built in the Ming and Qing Dynasties and other cultural scenic spots are all the key cultural relics protection units of the state. Here, the beautiful scenery and outstanding people have nurtured the famous Business Saint - Fan Li, the great historian - Fan Ye, the famous materialist thinker - Fan Zhen and other historical figures who have an important influence on the today's world.

\section{The SignifiCANCE OF CONDUCTING THE StUdy OF REGIONAL CULTURE}

Culture is the product of the human society development and plays a role in promoting the development and progress of human society to some extent. Historically, the growth and accumulation of human civilization is inseparable from the support of culture; from today's perspective, culture is highly integrated with more and more tertiary industries and sunrise industries; from the perspective of future, as large as the country and the nation and as small as the region and enterprises, the final competition must be explained by cultural soft power, national culture, regional culture and corporate culture. The cultural industry is an ideology industry. In response, the transformation from ideology to real economic form must be supported by other industries, such as tourism. With the improvement of China's national strength, people's economic life has been greatly improved. As a result, people spend more and more time and needs for consumption, entertainment, relaxation and leisure, which brings unprecedented opportunities for the development of the cultural industry. Coupled with the policy and financial adjustment and support of the state and the government, the cultural industry has shown a booming trend.

Usually, the main reason why a place attracts tourists for the first time is the unique culture of this place. Culture has immeasurable social, economic and ecological values. Culture is the driving force for the development of human society from low to high level. Without the power of culture, human society cannot develop from primitive state to modern civilization. Since entering the new century, the cultural tourism industry has become a new economic growth point in the new era as a sunrise industry. The development of the cultural tourism industry fully reflects the requirements of the scientific development concept.

\section{The CANAl HeAd Cultural Resources of South- TO-NORTH WATER TRANSFER CENTRAL LINE}

\section{A. Water Culture}

The canal head of the South-to-North Water Transfer Project middle line, which is the worlds most eye-catching is 
characterized by magnificence and far-reaching meaning. Rich water source and excellent water quality make Danjiang Reservoir the water source and canal head of the South-North Water Transfer Project. The root of Xichuan culture lies in Danjiang and Danjiang is the source of regional culture in Xichuan. Many cultural phenomena in Xichuan are derived from Danjiang. Danjiang runs through the whole territory of Xichuan, with a length of 116.6 kilometers in the county and a drainage area of 2,237 square kilometers, accounting for $93.5 \%$ of the total area of the county. Because of the Danjiang River, there will be many cultural relics on both sides of the strait, such as the story that Danzhu, who is the son of Yao combated the river and died at his post; Chu culture originated here; Jingzi Pass, a key commercial town, Li Guanqiao rose here. And also because of Danjiang, there will be Danjiangkou Reservoir, the great migration of canal head of South-to-North Water Transfer project and the development opportunities for ecological construction of the canal head.

The 5,000-year-old Chinese civilization is extensive and profound with a long history. It is mainly composed of the two main veins of the Yellow River culture and the Yangtze River culture through long-term conflict, impact, penetration, integration, and final merger and developed and continues to this day. Danjiang, from the perspective of China's geographical latitude, it belongs to the north in the traditional sense of China's vast territory. However, from the perspective of the water system, it is the largest tributary of Hanshui, the largest tributary of the Yangtze River in China. Moreover, it is also the only north-south flow in northern China, communicating with the Yellow River Basin and the Yangtze River Basin as well as the only large river suitable for shipping. This special geographical coordinate makes Danjiang not only the origin of $\mathrm{Chu}$ culture, which is one of the main representatives of the Yangtze River culture, but also the earliest natural channel to communicate the two cultural circles of China because it is located at the junction of the two major cultural plates. This geographical advantage gives Danjiang a very complex and rich cultural deposit, with a certain cultural symbolic meaning. As a special cultural small section at the junction of the three provinces in southwestern Henan, Danjiang plays an important role in the history of Chinese culture. Excavating and studying it will help the origin of Chu culture to be traced, and it is of great value for solving the mystery of the convergence of the two cultural circles of China. In addition, it is more conducive to the organic integration of the Xichuan cultural industry. As the mother river of Xichuan people, Danjiang has also invigorated the economic and cultural development of Xichuan while raising the people there. It is wise for Xichuan to regard the Danjiang water culture as a symbol and a brand of regional culture.

\section{B. Chu Du Culture}

The canal head is the birthplace of Chu culture with a long history. It has rich remains and splendid cultural relics. The area has a long history, profound cultural heritage, numerous historical sites and celebrities, especially outstanding Chu culture.

The canal head is the cradle of the extensive and profound Chu culture. In 1978, China carried out archaeological excavations on 25 tombs of the Chu State aristocrats in the Spring and Autumn period and five large car-horse pits along the Danjiang River in Xichuan. In the process of excavation, the harvest is huge. Many historical and cultural heritages were unearthed here. For example, in this archaeological excavation, a large number of $\mathrm{Chu}$ cultural relics were unearthed, including more than 10,000 pieces of bronze tripods, chariots and horses, musical instruments and jade articles. In addition, there are stone panpipe (not only found for the first time in China, but also the earliest time?) and stone chime, showing the glorious and amazing $\mathrm{Chu}$ culture in the Spring and Autumn period.

Thousands of years ago, as the cradle of Chu culture, Xichuan gave birth to a splendid historical and cultural heritage. As the mother river of the Xichuan people, Danjiang played a pivotal role in the formation and development of Chu culture. It continuously injected blood and power into the development of Xichuan, and brought the Xichuan Chu culture into the profound Chinese culture, making tremendous contributions to the prosperity of the Chinese civilization. Xichuan, as the canal head, contributes to the world not only the water resources with amazing regenerative capacity, but also the long-standing Chu culture. For the development of contemporary Chinese cultural tourism industry, its tourism value and historical culture are pretty precious wealth.

\section{The Culture of Commercial Saint}

The Danjiang area is a place of outstanding people, and Xichuan, the canal head of the river is the hometown of Fan Li, who is called Commercial Saint. The Chu culture of Danjiang bred a famous politician, great strategist and great economistFan Li in the late Spring and Autumn Period. According to the records of ancient books such as "Historical Records" and "Annals of $\mathrm{Wu}$ and Yue ", the folk unrestrained scholars who was born in the Sanhu Township of Wan District of the Chu State, and was an encyclopedic mind, was dispatched to assist the Yue State in the early years by the Chu State. With his great wisdom and bravery, excellent diplomatic and military abilities, he urged Goujian, the king of Yue, to insist on " sleeping on the brushwood and taste the gall -- to nurse vengeance ".Finally, Yue State turned into strength, destroyed Wu State, and realized hegemony, thus rewriting the history of Spring and Autumn. Later, he retired from offices and lived in seclusion with his ability to judge the situation, which helped him to die a natural death. Then, he secretly concealed his identity in the Donghai area of Qi State to engage in planting, raising livestock, fishing and salt manufacturing industry and trade activities. Because of skillfulness at business, he became a man of nabobism. Later, he was appointed as a prime minister of Qi State. However, he was not greedy for wealth, and he dispersed his fortune and moved to the commercial center, Tao District (now in the area of Feicheng, Shandong), and continued to do business. Eventually, he became an exceedingly wealthy businessman so that he was later called Tao Zhugong, and was honored as a "commercial saint." Fan $\mathrm{Li}$ is a perfect and successful figure in the history of the world and he is a rare generalist. His great thoughts have had a profound influence on later generations. And he can be regarded as a synthesizer of the Chinese cultural spirit in the 
pre-Qin period. Together with Laozi, Zhuangzi and Qu Yuan, he became a representative of Chu culture.

What Fan Li most commended later was his "three moves" in his life, that is, act as the occasion demands, constantly changing the premises, occupations, names and other social roles. His series of successful examples and incisive remarks have formed a system of cultural spirit and have accumulated as the most outstanding part of the traditional culture of the Chinese nation. Many idioms that are still living in Chinese and full of philosophical content, such as "sleep on the brushwood and taste the gall — to nurse vengeance", "build up one's strength to avenge an insult", "retire after winning merit" "live in seclusion", "danger past, god is forgotten; cunning hare dies, hound is boiled", "seize the chance, because there is no time to come again, take the chance, or penalty will come to you", "select the right talent and take the advantageous situation", "both peasants and traders are beneficial", "The business is good", "earn a thousand pieces of gold three times", "disperse all one's fortunes" etc., have a direct relationship with Fan Li.

\section{Ming and Qing Dynasties Culture}

The famous historical and cultural town of China - Jingzi Pass Town is located in the northwest of canal head-Xichuan County, the junction of Hubei, Henan and Shaanxi provinces. It is known for its ancient streets in Ming and Qing Dynasties, the "three provinces of crow" and the simple folk customs. Jingzi Pass Town has strong economic strength and since ancient times, it has been the most prosperous social and economic center in the border areas of the three provinces, having greater radiation influence on the three provinces.

The prosperity of Xichuan in the past was mainly due to the benefits of the boat provided by Danjiang throughout the whole territory. The ancient Danjiang River has a large amount of water. In particular, it has a north-south flow that is very rare in the northern rivers of China, and has become a golden waterway that connecting the central Shaanxi plain in the north and Jianghan plain in the south. Before the opening of the Jing-han Railway, it was the main artery of the north-south waterway that echoed the Beijing-Hangzhou Grand Canal. It is precisely the shipping history of Danjiang for thousands of years, especially the great development of the Danjiang River in the Ming and Qing Dynasties that gave birth to Jingzi Pass of the Three Provinces of Crow, which was the northern water transport center and the largest commercial port on the Danjiang River of 800-mile long.

"One foot in three provinces" is undoubtedly the most attractive tourist highlight of Jingzi Pass. According to statistics, on the vast territory of China, there are about 40 places in the border of the three provinces and even the borders of the four provinces. However, in the vicinity of all the borders, there are few big market towns such as Jingzi Pass that are very famous and quite prosperous. Because the distance between the three places is too close, it can be said that "people could hear each other's cocks crow and dogs bark". As long as there is a rooster humming in the morning, the cocks in other two provinces will scream. When one starts singing, the others join in and they awaken the night together.
Therefore, there is a saying that "Jingzi Pass of the Three Provinces of Crow". However, with the passage of time, due to the decline of the Danjiang water level and the siltation of the river, the big ship has not been able to drive up to Jingzi Pass; moreover, because the Jing-han Railway is open to traffic, the north-south traffic line moves eastward. In response, the flourishing of this commercial and trade town, which has been prospering for hundreds of years no longer exists from then on. The prosperous Jingzi Pass has irrevocably declined, becoming a border town and a big business port that was abandoned by history. However, it has left a glorious and proud position in the political and economic history of southwestern Henan. The 700 -year-old building, which has been basically preserved so far, has recorded its bustling pictures.

This street built in the Ming and Qing Dynasties is more than two kilometers long and is built along the Danjiang River. It is generally north-south trend and divided into three sections: the south, the middle and the north. Every street is straight, but at the junction of the three streets, it turns a diagonal bend to form a large curve of "S" shape, thus avoiding the unobstructed monotony and showing surprising visual disparity. There are more than 700 Ming and Qing style buildings in Wuli Ancient Street. Most of them are preserved in the original appearance. It is the largest and most complete ancient street of Ming and Qing Dynasty in the 13 provinces in northern China and it has been listed as a national key cultural relics protection unit. Jingzi Pass of the Three Provinces of Crow is a large-scale commercial port in the Central Plains that flourished along with the prosperity of Danjiang shipping during the Ming and Qing Dynasties. It has been bustling for hundreds of years.

\section{The DisSEMination OF CUltural RESOURCES OF CANAL HEAD}

Xichuan, a county located at the middle route of the Southto-North Water Transfer Project is a cultural county with rich cultural and historical heritages. In particular, the special regional location makes it embrace the interactive influence of the Central Plains culture, the Sanqin culture and the Jingchu culture, forming a distinct Xichuan culture with distinctive regional characteristics. Today, facing new opportunities, as the canal head of the middle route of the South-to-North Water Transfer Project, supported by the strong policies and funds of the state and the government, Xichuan must seize this rare historical opportunity to establish the development concept of "cultural county, tourism county, and the high-level integration of cultural and tourism". While focusing on promoting existing natural resources, it is necessary to have a strong sense of cultural heritage and development. Xichuan should integrate culture into the development of tourism industry to create innovative and competitive cultural tourism products and attract visitors from all over the world. It is wise for the county to promote tourism by means of culture and then achieve the purpose of building a competitive tourism county.

\section{CONCLUSION}

The canal head should rely on the beautiful landscape and high-quality ecological environment of the middle line of the South-to-North Water Transfer Project, focus on the cultural 
tourism industry, adhere to the ecological basis, and develop the economic development in line with the people's livelihood to build up national demonstration area of water culture-based ecological tourism and ecotourism destination of world artificial lakes characterized by water culture and they should regard the lake ecotourism as the main function. At the same time, the canal head of middle line of the South-to-North Water Transfer Project should establish a global-style ecoleisure holiday destination with the theme of Chu culture, water culture, Buddhism culture, ancient town culture, Commercial Saint culture and folk customs, with water sightseeing and eco-tourism as the driving wings. In this process, the path of differentiated development should be taken.

\section{REFERENCES}

[1] Chen Xianfu, Yang Qiao. Research on the Integrated Development of Tourism Industry and Cultural Industry in Guizhou. China Collective Economy, 2018(16).

[2] Wang Shengzhi. Analysis on the Eco-Cultural Tourism in the Middle Route of South-to-North Water Transfer Project. Management Observer, 2013(20) .

[3] Ma Cheng. The Development of the Characteristic Works of Folk Art in Northern Shaanxi in the Tourism Industry. Modern Marketing, 2018(5) . 